\title{
Origin of passivation in hole-selective transition metal oxides for crystalline silicon
}

\section{heterojunction solar cells}

Luis G. Gerling ${ }^{\mathrm{a}, \mathrm{b}, *}$, Cristobal Voz ${ }^{\mathrm{a}}$, Ramón Alcubilla ${ }^{\mathrm{a}, \mathrm{b}}$, Joaquim Puigdollers ${ }^{\mathrm{a}, \mathrm{b}}$

${ }^{a}$ Electronic Engineering Department, Universitat Politècnica de Catalunya, Jordi Girona 1-

3, 08034, Barcelona, Spain

${ }^{\mathrm{b}}$ Centre de Recerca en Nanoenginyeria, Pascual i Vila 15, 08028, Barcelona, Spain

* Corresponding author. Tel.:+34 93401 1002; fax: +34 934016756.

E-mail address: guillermo.gerling@upc.edu

\section{ABSTRACT}

Transition metal oxides (TMOs) have recently attracted interest as an alternative to boron/phosphorous doped layers in crystalline silicon heterojunction solar cells. In this work, the interface between n-type c-Si (n-Si) and three thermally evaporated TMOs $\left(\mathrm{MoO}_{3}, \mathrm{WO}_{3}\right.$ and $\left.\mathrm{V}_{2} \mathrm{O}_{5}\right)$ was investigated by transmission electron microscopy and secondary ion-mass/x-ray photoelectron spectroscopy. For the oxides studied, chemical passivation of n-Si was attributed to an ultra-thin $(1.9-2.8 \mathrm{~nm}) \mathrm{SiO}_{\mathrm{x} \sim 1.5}$ interlayer formed by chemical reaction, leaving oxygen-deficient species $\left(\mathrm{MoO}, \mathrm{WO}_{2}\right.$ and $\left.\mathrm{VO}_{2}\right)$ as byproducts. Field-effect passivation was also inferred from the inversion (hole-rich) layer induced on the n-Si surface, a result of Fermi level alignment between two materials with dissimilar electrochemical potentials (work function delta $\Delta \phi \geq 1 \mathrm{eV}$ ). Therefore, the holeselective and passivating functionality of these TMOs, in addition to their ambient temperature processing, could prove an effective means to lower cost and simplify solar cell processing. 


\section{INTRODUCTION}

As today's photovoltaic market continues to be dominated by crystalline silicon (cSi) technology, two cost-reduction efforts are being contemplated: thinner silicon wafers (< $100 \mu \mathrm{m})$ and the use of novel materials deposited at low temperatures with high throughput processes. Maximization of the solar cell open-circuit voltage $\left(V_{O C}\right)$ to record values of 750 $\mathrm{mV}$ [1] has been possible by combining two principles of solar cell design [2]: (1) chemical passivation of surface dangling bonds with hydrogenated amorphous silicon (a-Si:H) and other dielectrics $\left(\mathrm{SiO}_{2}, \mathrm{Al}_{2} \mathrm{O}_{3}, \mathrm{Si}_{3} \mathrm{~N}_{4}, \mathrm{SiC}\right)$; and (2) field-effect passivation by inducing a carrier-concentration gradient via electron- and hole-selective contacts, traditionally achieved by phosphorous/boron doping. Eventually, the ideal and simplest strategy would require a passivating/selective contact, dual-functionality materials that effectively passivate the c-Si surface while selectively conduct a specific charge carrier $\left[{ }^{3},{ }^{4}\right]$.

In parallel, thin-film photovoltaics including organic and perovskite solar cells, have introduced a wide variety of electron- and hole-selective materials whose optoelectronic properties are comparable or superior to the standard p- and n-doped layers used in c-Si. Despite being quite different from silicon's properties and technology, such materials have been successfully applied to c-Si heterojunction devices by low temperature $\left(\mathrm{T}<200^{\circ} \mathrm{C}\right.$ ) and solution-based processes, including organics $\left[{ }^{5}\right]$, alkali salts $\left[{ }^{6},{ }^{7}\right]$ and transition metal oxides (TMOs) $\left[{ }^{8-18}\right]$. TMOs offer themselves as excellent candidates to substitute traditional c-Si dopants given their wide range of work function values $(3-7 \mathrm{eV})$ and marked p- or n-type semiconductivity $\left[{ }^{19}\right]$. Additionally, their semi-insulating properties allow for passivation of the c-Si surface without compromising carrier-conductivity, although their passivation potential in abrupt TMO/c-Si heterojunctions is limited to experimental $V_{O C}$ values of $\sim 680 \mathrm{mV}\left[{ }^{11,20}\right]$. This has prompted the use of a-Si:H 
passivating interlayers in order to surpass the $700 \mathrm{mV}$ barrier, as has been demonstrated by a $725 \mathrm{mV} V_{O C}$ and a $22.5 \%$ conversion efficiency device with $\mathrm{MoO}_{3}$ hole contacts $\left.{ }^{21}\right]$. Therefore, a detailed understanding of the surface passivation mechanisms occurring at the TMO/c-Si interface (either by chemical bonding, charge selectivity or both) is still needed to potentiate the use of these passivating/carrier-selective materials.

In this work we will explain the origin of passivation in three TMO/n-type c-Si (n$\mathrm{Si})$ heterojunctions, molybdenum trioxide $\left(\mathrm{MoO}_{3}\right)$, tungsten trioxide $\left(\mathrm{WO}_{3}\right)$ and vanadium pentoxide $\left(\mathrm{V}_{2} \mathrm{O}_{5}\right)$, deposited by vacuum thermal evaporation. The heterojunction interface will be characterized in detail by microscopy (TEM) and spectroscopy (ToF-SIMS, XPS) techniques, establishing two contributions to c-Si surface passivation: 1) through chemical reaction between c-Si and TMOs; and 2) via carrier-concentration gradients established during Fermi level alignment under equilibrium.

\section{EXPERIMENTAL}

Sample structures were fabricated on polished float-zone Si wafers (100 orientation) with a thickness of $280 \mu \mathrm{m}$ and $2.5 \Omega$-cm resistivity. After RCA standard cleaning, wafers were dipped in $1 \% \mathrm{HF}$ during 1 min to etch $\mathrm{SiO}_{2}$ away. In this step, the surface $\mathrm{Si}$ atoms become bonded to hydrogen to form a continuous H-terminated surface. Unfortunately, this configuration is unstable and will be substituted by an ultra-thin native $\mathrm{SiO}_{2}$ layer after only a few minutes $\left.{ }^{22}\right]$. Therefore, special care was taken to avoid a long air exposure $(<30$ seconds) by transferring the HF-cleaned wafers into a $\mathrm{N}_{2}$ glovebox before TMO deposition. The three transition metal oxides, $\mathrm{MoO}_{3}, \mathrm{WO}_{3}$ and $\mathrm{V}_{2} \mathrm{O}_{5}$ (powdered 99.99\%, Sigma Aldrich) were thermally evaporated under vacuum $\left(<8 \times 10^{-6}\right.$ mbar $)$ from a tantalum boat at a rate $\sim 0.2 \dot{\mathrm{A}} / \mathrm{s}$. Films thicknesses were measured by quartz crystal micro-balance at 70, 25 and $5 \mathrm{~nm}$ for $\mathrm{MoO}_{3}, \mathrm{WO}_{3}$ and $\mathrm{V}_{2} \mathrm{O}_{5}$ respectively. During the evaporation process, heating 
of the Si substrate was negligible and remained at ambient temperature. After a brief air exposure, samples were transferred to a RF-magnetron sputtering chamber for deposition of an $80 \mathrm{~nm}$ indium-tin oxide (ITO) film, under an argon partial pressure of $3.5 \times 10^{-3}$ mbar and $50 \mathrm{~W}$ power. This ITO layer, which works as a transparent conducting layer in a TMO/n-Si solar cell, protects the layers beneath from degradation and work function changes $\left[{ }^{23}\right]$.

These ITO/TMO/n-Si structures were first characterized by High Resolution Transmission Electron Microscopy (HR-TEM), using lamellas prepared by Focused Ion Beam (FIB) milling with $\mathrm{Ga}^{+}$ions (Carl Zeiss NEON40). Cross-sectional HR-TEM imaging (Jeol 2010F) was done with a field-emission electron source at $200 \mathrm{KV}$ and lattice resolution. Secondly, Time of Flight Secondary Ion-Mass Spectroscopy (ToF-SIMS) depth profiling (IONTOF Model IV) was performed by sputtering a sampling area of 300 x 300 $\mu \mathrm{m}^{2}$ with $\mathrm{Cs}^{+}$ions $(1 \mathrm{keV})$ at high vacuum (3.8 $\left.\times 10^{-8} \mathrm{mbar}\right)$. The analysis of the sputtered secondary ions (negative) was done with a $\mathrm{Bi}^{+1}$ source $(25 \mathrm{keV})$ and a time resolution of 200 ps. Charge compensation $(<20 \mathrm{eV})$ was applied via electron flooding, given the semiinsulating character of TMOs.

For the X-ray Photoelectron Spectroscopy (XPS) scans, separate samples were prepared ex-situ by thermally evaporating $\mathrm{V}_{2} \mathrm{O}_{5}$ at different thicknesses $(1-8 \mathrm{~nm})$ on $\mathrm{n}$-Si substrates (same conditioning as before). After oxide evaporation, each sample was transferred from the glovebox into the XPS chamber after a brief air exposure. The XPS analysis (SPECS, Phoibos 150 detector) was performed at $3 \times 10^{-9}$ mbar using a nonmonochromatic Al-Ka source $(1486.6 \mathrm{eV})$ and a $90^{\circ}$ incidence angle guaranteeing a probing depth of at least $10 \mathrm{~nm}$. Deconvolution of the core level spectra was done by Gaussian-Lorentzian fittings after Shirley background substraction, while percentage atomic concentrations were calculated from the integration of the fitted peak areas. When 
quantifying the oxygen content, correction for adventitious carbon $\mathrm{C}-\mathrm{OH}$ and $\mathrm{C}-\mathrm{O}$ contamination ( $<15 \%$ atomic C content) was performed. Unless stated otherwise, all binding energies were referenced to the $\mathrm{Si} 2 \mathrm{p} 3 / 2$ peak $(99.5 \mathrm{eV})$ of the clean Si sample.

\section{RESULTS AND DISCUSSION}

\section{A. Interlayer in TMO/c-Si interfaces}

As a first approach, detailed imaging of the fabricated ITO/TMO/c-Si structures was performed by HR-TEM, revealing the presence of an unknown $1-2 \mathrm{~nm}$ thick interfacial layer between the TMOs and the HF-cleaned (and therefore $\mathrm{SiO}_{2}$ free) c-Si surface. This interlayer (IL), amorphous in nature, is clearly distinguished at the lowest magnifications [Fig. 1(a)] because of its high contrast to the adjacent materials. Its thickness varies among the three TMOs [Fig. 1(b) - (d)] but is relatively uniform and without pinholes. Moreover, its shows an abrupt interface with c-Si and a somewhat diffused one with the oxides. The maximum IL thicknesses are $\sim 2.8 \mathrm{~nm}\left(\mathrm{WO}_{3}\right), \sim 2.5 \mathrm{~nm}\left(\mathrm{MoO}_{3}\right)$ and $2.2 \mathrm{~nm}\left(\mathrm{~V}_{2} \mathrm{O}_{5}\right)$, all of which are greater than the maximum threshold for tunneling $(\sim 1.2 \mathrm{~nm})\left[{ }^{2}\right]$, suggesting another charge conduction mechanism must be present.
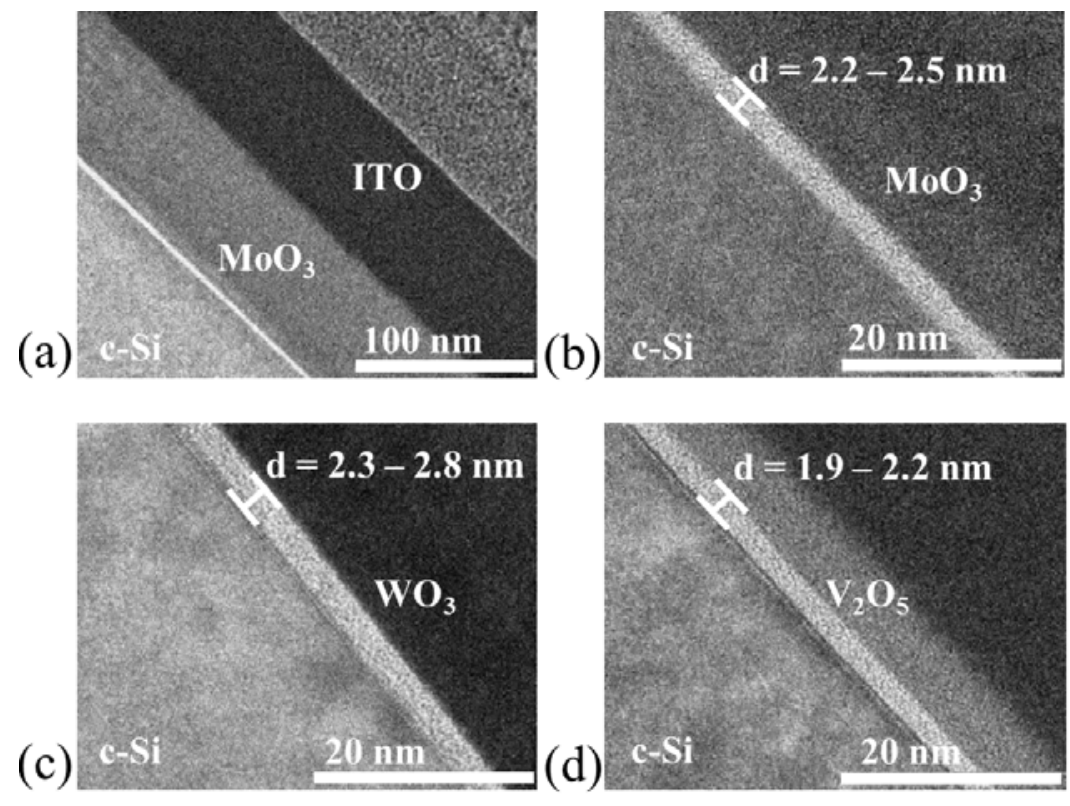
FIG. 1. HR-TEM images of the ITO/TMO/c-Si heterostructures showing an interlayer between c-Si and $\mathrm{MoO}_{3}(\mathrm{a}-\mathrm{b}), \mathrm{WO}_{3}$ (c) and $\mathrm{V}_{2} \mathrm{O}_{5}(\mathrm{~d})$.

Next, the interlayer composition was qualitatively determined by ToF-SIMS. Figure 2(a) shows the global depth profile of the ITO/MoO $/ \mathrm{n}$-Si sample, where the three distinct materials are clearly differentiated by their respective ions $\mathrm{InO}_{2}{ }^{-} / \mathrm{SnO}_{2}{ }^{-}, \mathrm{MoO}_{3}{ }^{-}$and $\mathrm{Si}^{-}$. Extraneous elements include carbon and fluoride $\left(\mathrm{C}^{-}, \mathrm{F}^{-}\right)$, found mainly at the material interfaces and related to organic contamination during air exposure and to the HF dips respectively. By increasing the resolution of the time scale [Fig. 2(b)], a signal with an atomic mass unit (amu) of 59.97 and a peak intensity of $3 \times 10^{3}$ counts is observed in the $\mathrm{MoO}_{3} / \mathrm{n}$-Si interface, corresponding to $\mathrm{SiO}_{2}{ }^{-}$ions. Since the HF-cleaned silicon surface is free of any native oxide (as will be confirmed later by XPS), the presence of $\mathrm{SiO}_{2}{ }^{-}$ions suggests that a thin silicon oxide IL has grown during thermal evaporation of $\mathrm{MoO}_{3}$, proving that chemical passivation of dangling bonds by oxygen actually occurs. Within the same time window, a reduced $\mathrm{Mo}^{+2}$ oxide $\left(\mathrm{MoO}^{-}\right)$signal is detected, indicating it is a byproduct of the incomplete oxidation of the $\mathrm{Si}$ surface by $\mathrm{MoO}_{3}\left(\mathrm{Si}+\mathrm{MoO}_{3} \rightarrow \mathrm{SiO}_{2}+\right.$ MoO). Since remnants of the HF etch are also observed, it can be confirmed that such interlayer is restricted to the TMO/n-Si interface. A compound $\mathrm{SiO}_{2}-\mathrm{MoO}_{3}$ signal was also detected but at quite low intensities ( $<10^{2}$ counts), more than two orders of magnitude lower than the $\mathrm{SiO}_{2}$ signal and following the same trend. Therefore, the probability of a having a silicate-like $\mathrm{Mo}_{\mathrm{x}} \mathrm{Si}_{\mathrm{y}} \mathrm{O}_{3}$ composition in the $\mathrm{IL}$ is low although it cannot be fully discarded. Finally, a $\mathrm{SiOH}^{-}$ion signal is also detected but 10 times smaller than $\mathrm{SiO}_{2}$, suggesting it is also related to adventitious contamination. 


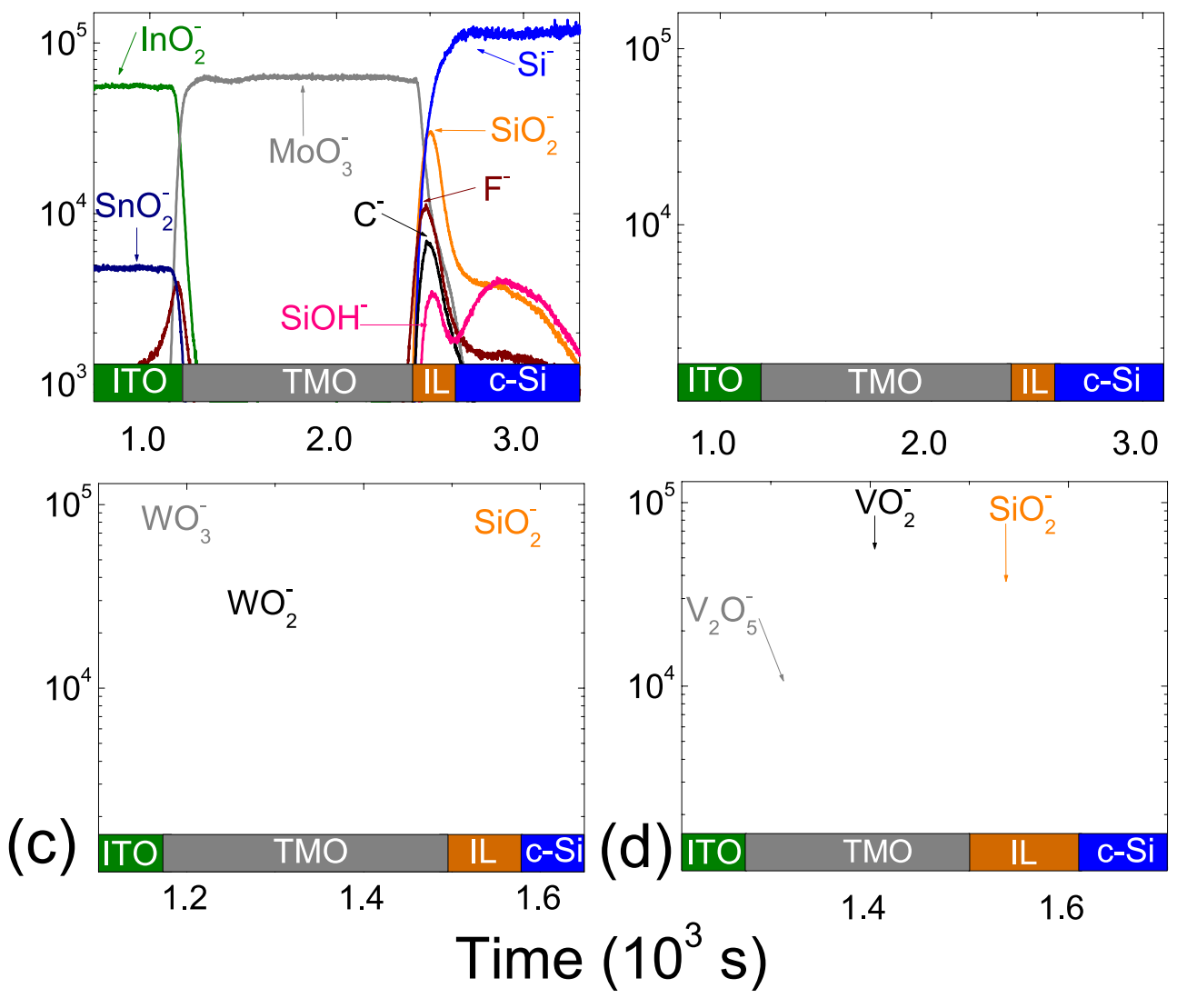

FIG. 2. ToF-SIMS depth profile for the ITO/TMO/c-Si heterostructures showing a $\mathrm{SiO}_{2}{ }^{-}$ signal at the interface between c-Si and $\mathrm{MoO}_{3}(\mathrm{a}-\mathrm{b}), \mathrm{WO}_{3}(\mathrm{c})$ and $\mathrm{V}_{2} \mathrm{O}_{5}(\mathrm{~d})$. For each TMO, related reduced species $\left(\mathrm{MoO}^{-}, \mathrm{WO}_{2}^{-}, \mathrm{VO}_{2}^{-}\right)$are also detected near the interface. Also shown in (a) are the $\mathrm{F}^{-}, \mathrm{C}^{-}$and $\mathrm{SiOH}^{-}$signals, attributed to surface contamination of the HF-treated c-Si substrate after air-exposure. (Color Online).

Similarly, the silicon oxide peak is also detected in the $\mathrm{WO}_{3} / \mathrm{n}-\mathrm{Si}$ and $\mathrm{V}_{2} \mathrm{O}_{5} / \mathrm{n}-\mathrm{Si}$ interfaces in Fig. 2(c-d), at similar intensities and associated with reduced TMO species located adjacent to the interface $\left(\mathrm{WO}_{2}, \mathrm{~V}_{2} \mathrm{O}_{4}\right)$. In fact, since the vanadium oxide layer is the thinnest, the extent of the reduction reaction is greater and $\mathrm{VO}_{2}{ }^{-}$species surpass $\mathrm{V}_{2} \mathrm{O}_{5}$ in intensity. Moreover, since the $\mathrm{SiO}_{2}{ }^{-}$peak intensities are about the same order of magnitude as their respective TMO signals (3.0-6.0 x10 4 counts), it means that the $\mathrm{SiO}_{2}$ layer is conformal and uniform across the analyzed area, in agreement with the TEM images. 
Finally, $\mathrm{SiOH}^{-}$and silicate signals were also detected in the $\mathrm{WO}_{3}$ and $\mathrm{V}_{2} \mathrm{O}_{5}$ samples but at the low intensities mentioned before, leading to the same conclusions.

With respect to the abundant presence of the $\mathrm{F}^{-}$ions $\left(1.0 \times 10^{4}\right.$ counts $)$ and its effect on the interface, a separate $\mathrm{V}_{2} \mathrm{O}_{5}$ sample was washed with abundant deionized water after the $\mathrm{HF}$ dip, decreasing the $\mathrm{F}^{-}$intensity by a factor of 2 (not shown) while the $\mathrm{SiO}_{2}^{-}$ remained unchanged. Since Si-F terminations are not kinetically viable during HF etching, it is probable these $\mathrm{F}^{-}$are only physisorbed $\left[{ }^{22}\right]$. However, preliminary tests on finished solar cell devices prepared with and without the deionized $\mathrm{H}_{2} \mathrm{O}$ quench indicate that $\mathrm{F}^{-}$is not detrimental to the passivation or transport properties of these structures.

\section{B. Thermodynamic feasibility}

The formation of a $\mathrm{SiO}_{2}$ layer on a H-terminated Si surface can only be explained by chemical reaction with TMOs during deposition. The growth of $\mathrm{SiO}_{\mathrm{x}}$ interlayers on c-Si has been previously reported for dielectric oxides $\mathrm{Al}_{2} \mathrm{O}_{3}, \mathrm{HfO}_{2}, \mathrm{Ta}_{2} \mathrm{O}_{5}, \mathrm{LaAlO}_{3}$ and $\mathrm{SrTiO}_{3}$, with interlayers varying from 0.7 to $9 \mathrm{~nm}$ in thickness and diverse stoichiometries $\left(\mathrm{SiO}_{\mathrm{x}}\right.$,

$\left.\left.\mathrm{Hf}_{1-\mathrm{x}} \mathrm{Si}_{\mathrm{x}} \mathrm{O}_{2}\right){ }^{24-26}\right]$. This is partially explained by the high reactivity of H-terminated $\mathrm{Si}\left[{ }^{22}\right]$, but also from purely thermodynamic considerations. Parting from the oxidation of metallic Si and $\mathrm{V}$ by molecular $\mathrm{O}_{2}$, the feasibility of these reactions is given by their negative Gibbs formation energies $(\Delta \mathrm{G})$ :

$$
\begin{array}{ll}
5 / 2 \mathrm{Si}+\frac{5}{2} \mathrm{O}_{2} \rightarrow 5 /{ }_{2} \mathrm{SiO}_{2} & \Delta \mathrm{G}_{\mathrm{Si}-\mathrm{O} 2}=-858 \mathrm{~kJ} / \mathrm{mol} \\
2 \mathrm{~V}+{ }^{5} / 2 \mathrm{O}_{2} \rightarrow \mathrm{V}_{2} \mathrm{O}_{5} & \Delta \mathrm{G}_{\mathrm{V}-\mathrm{O} 2}=-573 \mathrm{~kJ} / \mathrm{mol}
\end{array}
$$

For the case where $\mathrm{Si}$ is oxidized by $\mathrm{V}_{2} \mathrm{O}_{5}$, the vanadium oxidation reaction should be subtracted from the silicon one, leading to:

$$
{ }_{2}^{5} \mathrm{Si}+\mathrm{V}_{2} \mathrm{O}_{5} \rightarrow{ }^{5} / \mathrm{SiO}_{2}+2 \mathrm{~V} \quad \Delta \mathrm{G}_{\mathrm{Si}-\mathrm{V} 2 \mathrm{O} 5}=\Delta \mathrm{G}_{\mathrm{Si}-\mathrm{O} 2}-\Delta \mathrm{G}_{\mathrm{V}-\mathrm{O} 2}=-285 \mathrm{~kJ} / \mathrm{mol}
$$


Hence, the oxidation of Si by a deposited metal oxide is thermodynamically feasible (spontaneous) if its Gibbs formation energy is less negative than the Gibbs formation energy of $\mathrm{SiO}_{2}$. The same condition is met for the rest of the TMOs under study, with $\Delta \mathrm{G}_{\mathrm{Si} \text { - }}$ wO3 $=-348$ and $\Delta \mathrm{G}_{\mathrm{Si}-\mathrm{MoO} 3}=-406 \mathrm{~kJ} / \mathrm{mol}$, using the standard Gibbs formation energies from

$\left[{ }^{27}\right]$ at $300 \mathrm{~K}$. An exception to this rule is observed for $\mathrm{HfO}_{2}$ and $\mathrm{Al}_{2} \mathrm{O}_{3}$ ( $\Delta \mathrm{G}$ positive), indicating that the spontaneity of these reactions is also affected by the initial equilibrium conditions, kinetic rates and the reactivity of the interface. Note also that any oxidation reaction essentially takes place by electron transfer, meaning that an electron loss in metallic Si yields an oxidized species $\left(\mathrm{Si}^{0}-2 \overline{\mathrm{e}} \rightarrow \mathrm{Si}^{+2}\right)$. This interpretation will be important when explaining Fermi level alignment between TMOs and n-Si (see Section E). Regarding the relative $\Delta$ Gs magnitude $\left(\mathrm{V}_{2} \mathrm{O}_{5}>\mathrm{WO}_{3}>\mathrm{MoO}_{3}\right)$, no correlation was found with IL thickness (Fig. 1) or the work function of air-exposed TMOs ( $\phi_{\mathrm{V} 2 \mathrm{O} 5} \sim 5.3$, $\phi_{\mathrm{WO}}$ $\left.\sim 5.0, \phi_{\mathrm{MoO3}} \sim 5.4 \mathrm{eV}\right)\left[{ }^{16}\right]$.

\section{XPS of TMO/interlayer/c-Si region}

As suggested before, the degree of completion of TMO-Si reactions could be less than unity, so that $\mathrm{Si}$ could partially oxidize $\left(\mathrm{Si}+\mathrm{V}_{2} \mathrm{O}_{5} \rightarrow \mathrm{SiO}_{\mathrm{x}}+\mathrm{V}_{2} \mathrm{O}_{5-\mathrm{x}}\right)$ and a mixture of sub-stoichiometric species would coexist in the interlayer. Therefore, a detailed chemical composition of the TMO/IL/n-Si interfaces was obtained from XPS analyses of $\mathrm{V}_{2} \mathrm{O}_{5}$ films deposited on n-Si at incremental thicknesses $(1-8 \mathrm{~nm})$, as a way to monitor film growth and the chemical/electronic changes taking place in the interface. Figure 3(a) shows the Si2p core level spectra as a function of binding energy, deconvoluted for the Si2p $\mathrm{p}^{3 / 2}$ doublet. For the reference case where no $\mathrm{V}_{2} \mathrm{O}_{5}$ is present, only one peak centered at $99.5 \mathrm{eV}$ 
binding energy can be observed, characteristic of the metallic $\mathrm{Si}^{0}$ substrate $\left[{ }^{28}\right]$. As soon as $1 \mathrm{~nm} \mathrm{~V}_{2} \mathrm{O}_{5}$ is deposited, an additional chemical state is detected at a higher binding energy of $102.0 \pm 0.1 \mathrm{eV}$ [Fig. 3(a) inset] and is discernible for thicker $\mathrm{V}_{2} \mathrm{O}_{5}$ films. This peak is attributed to sub-stoichiometric $\mathrm{SiO}_{\mathrm{x} \sim 1.5}$ species $\left.\left(\mathrm{Si}^{+3}\right){ }^{28,29}\right]$ and is identified as one of the components of the interlayer revealed by HR-TEM and ToF-SIMIS. As a reference, a stoichiometric $\mathrm{SiO}_{2}$ oxide grown by wet etching of c-Si with $\mathrm{HNO}_{3}$ is shown with its $\mathrm{Si}^{+4}$ peak at $103.2 \mathrm{eV}$. The sub-stoichiometry of the $\mathrm{SiO}_{\mathrm{x}}$ interlayer is quite relevant because it explains why its thickness (as measured by HR-TEM) does not represent a barrier for the transversal conduction of carriers. Instead, the conduction mechanism is via defects (oxygen vacancies) and is not limited by the maximum tunneling thickness of $\mathrm{SiO}_{2}$ passivation layers. The atomic $\mathrm{Si}^{3+}$ concentration in the IL was $0.9-2.0 \%$ and fairly constant for every sample, suggesting $\mathrm{SiO}_{\mathrm{x}}$ formation takes place during the first deposition stages until it saturates, remaining constant afterwards.

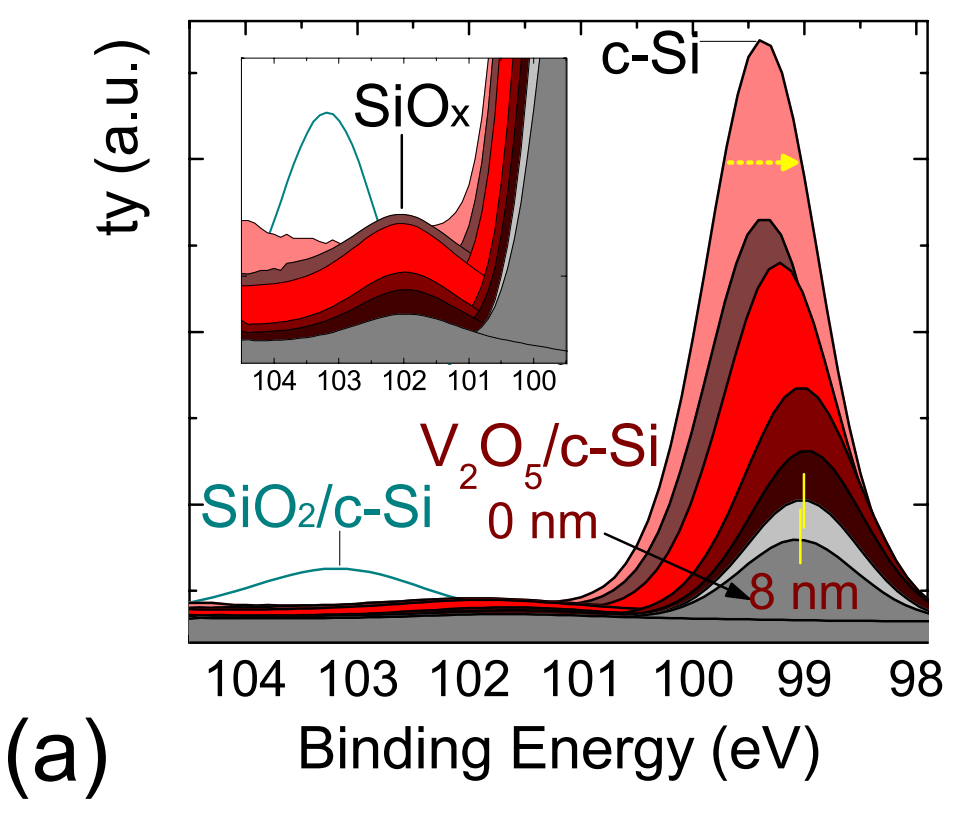




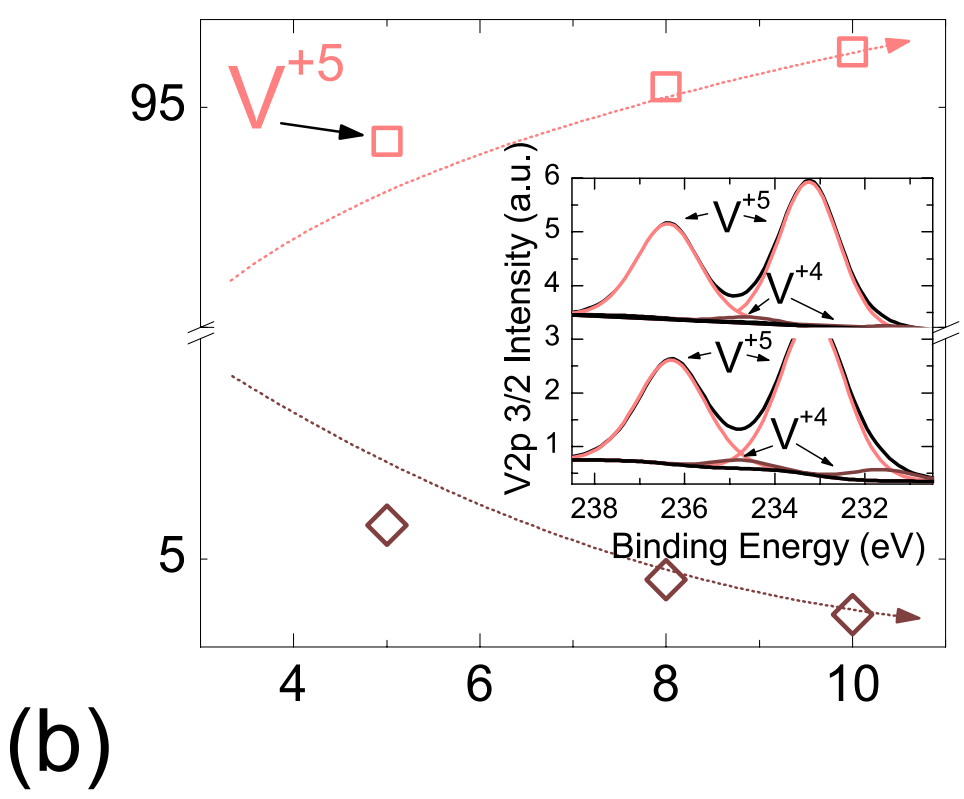

FIG. 3. XPS analysis of the $\mathrm{V}_{2} \mathrm{O}_{5}$ /interlayer/c-Si region at increasing $\mathrm{V}_{2} \mathrm{O}_{5}$ thicknesses $(1-$ $8 \mathrm{~nm}$ ). (a) Si2p $3 / 2$ doublet spectra showing the characteristic features of the silicon substrate $\left(\mathrm{Si}^{0}, 99.5 \mathrm{eV}\right)$, an stoichiometric $\mathrm{SiO}_{2} / \mathrm{c}-\mathrm{Si}$ reference $\left(\mathrm{Si}^{+4}, 103.2 \mathrm{eV}\right)$ and a substoichiometric $\mathrm{SiO}_{\mathrm{x} \sim 1.5}\left(\mathrm{Si}^{+3}, \sim 102.0 \mathrm{eV}\right)$ attributed to the $\mathrm{TMO} / \mathrm{c}-\mathrm{Si}$ interlayer. Inset shows a detailed view of these features. The peak maxima, marked with a vertical line, shifts to lower energies as thickness increases. The $\mathrm{Si} 2 \mathrm{p}^{1} / 2$ doublet, shifted $0.63 \mathrm{eV}$ to higher binding energies and smaller by a ratio 1:2, is omitted for clarity. (b) Evolution of the vanadium cation species $\mathrm{V}^{+4}$ and $\mathrm{V}^{+5}$ close to the c-Si interface. Inset shows the $\mathrm{V} 2 \mathrm{p}^{3} / 2$ doublet spectra showing the characteristic features of $\mathrm{V}^{+4}(516.5 \mathrm{eV})$ and $\mathrm{V}^{+5}(518.1 \mathrm{eV})$ states. The V2p $1 / 2$ doublet is shifted $7.6 \mathrm{eV}$ to higher binding energies. (Color Online).

Since the $\mathrm{Si} \rightarrow \mathrm{SiO}_{x}$ partial oxidation reaction implies a complementary $\mathrm{V}_{2} \mathrm{O}_{5} \rightarrow$ $\mathrm{V}_{2} \mathrm{O}_{5-\mathrm{x}}$ partial reduction, the XPS analysis of the vanadium V2p core level spectra should show the vanadium oxidation states involved. This is depicted in Fig. 3(b) inset where the 
$\mathrm{V} 2 \mathrm{p}^{3} / 2$ doublet is deconvoluted into two peaks centered at 518.1 and $516.5 \pm 0.1 \mathrm{eV}$ binding energies, corresponding to the $\mathrm{V}^{+5}$ and $\mathrm{V}^{+4}$ cation species $\left[{ }^{30}\right]$. The area of each cation provides the relative $\mathrm{V}^{+4}$ and $\mathrm{V}^{+5}$ atomic concentrations as a function of $\mathrm{V}_{2} \mathrm{O}_{5}$ film thickness [Fig. 3(b)]. The observed tendency is the following: $\mathrm{V}^{+4}$ species, associated to oxygen-deficient films $\left(\mathrm{V}_{2} \mathrm{O}_{\mathrm{x}<5}\right)$ and generated by reduction $\left(\mathrm{V}^{+5} \rightarrow \mathrm{V}^{+4}\right)$, are primarly found in the vicinity of the $\mathrm{SiO}_{\mathrm{x}} \mathrm{IL}$ and tend to decrease as the $\mathrm{V}_{2} \mathrm{O}_{5}$ film thickens; inversely, $\mathrm{V}^{+5}$ species are lowest (but still predominant) close to the IL and tend to increase until reaching a relatively fixed concentration in the bulk (away from the interface and its electronic influence). Similar trends have been observed previously for $\mathrm{MoO}_{3} /$ metal $\left[{ }^{31}\right]$ and $\left.\mathrm{MoO}_{3} / \mathrm{Si}{ }^{32}\right]$ systems, where reduced cation states $\left(\mathrm{Mo}^{+5}\right)$ exist near the oxidized interface. The presence of $\mathrm{V}^{+4}$ cations was already expected from the ToF-SIMS depth profiles, where $\mathrm{VO}_{2}{ }^{-}$ions were detected adjacent to the $\mathrm{SiO}_{\mathrm{x}}$ interlayer. Therefore, although no detailed XPS analyses were performed with incremental $\mathrm{WO}_{3}$ and $\mathrm{MoO}_{3}$ thicknesses, the similarity between the ToF-SIMS/HR-TEM results indicate that analogue interlayers with $\mathrm{SiO}_{\mathrm{x} \leq 2}$ composition and reduced cation transitions $\left(\mathrm{Mo}^{+6} \rightarrow \mathrm{Mo}^{+5}, \mathrm{~W}^{+6} \rightarrow \mathrm{W}^{+5}\right)$ can be expected as well, as has been recently confirmed by [ $\left.{ }^{33,34}\right]$.

\section{Film stoichiometry and growth mode}

Compared to the qualitative composition obtained from ToF-SIMS, XPS allows the quantification of film stoichiometries as oxygen to metal ratios (O/M). However, the specific distribution of oxygen species $\left(\mathrm{SiO}_{\mathrm{x}}, \mathrm{V}_{2} \mathrm{O}_{\mathrm{x}}\right)$ from the total oxygen content is not straightforward. To clarify this issue, we focus on the oxygen O1s XPS spectra shown in Figure 4 for the $\mathrm{V}_{2} \mathrm{O}_{5} / \mathrm{IL} / \mathrm{n}$-Si region. From the deconvolution of the spectra, two components representing different chemical states are recognized. The first (larger) 
component is centered at $530.9 \pm 0.3 \mathrm{eV}$, attributed to $\mathrm{O}$ in vanadium oxide $\left[{ }^{30}\right]$. The second (smaller) component is centered at a higher binding energy (532.3 $\pm 0.3 \mathrm{eV})$ and is detected for every $\mathrm{V}_{2} \mathrm{O}_{5}$ thickness $(1-8 \mathrm{~nm})$, comprising $\sim 25 \%$ of the total O1s area. This secondary-O, which has been previously described as a defective oxide inherent to many other TMOs $\left[{ }^{30}\right]$, has its source on surface hydroxides $(\mathrm{V}-\mathrm{OH})$ and adventitious carbon $(\mathrm{C}-$ O) physisorbed during exposure to humid air [ $\left.{ }^{31,35}\right]$ when transferred out of the glovebox into the XPS chamber. Additionally, the sub-stoichiometric $\mathrm{SiO}_{\mathrm{x}}$ of the underlying interlayer also contributes to this secondary-O, as it lies very close to the $\mathrm{SiO}_{2}$ reference (centered at $532.8 \mathrm{eV}$ ).

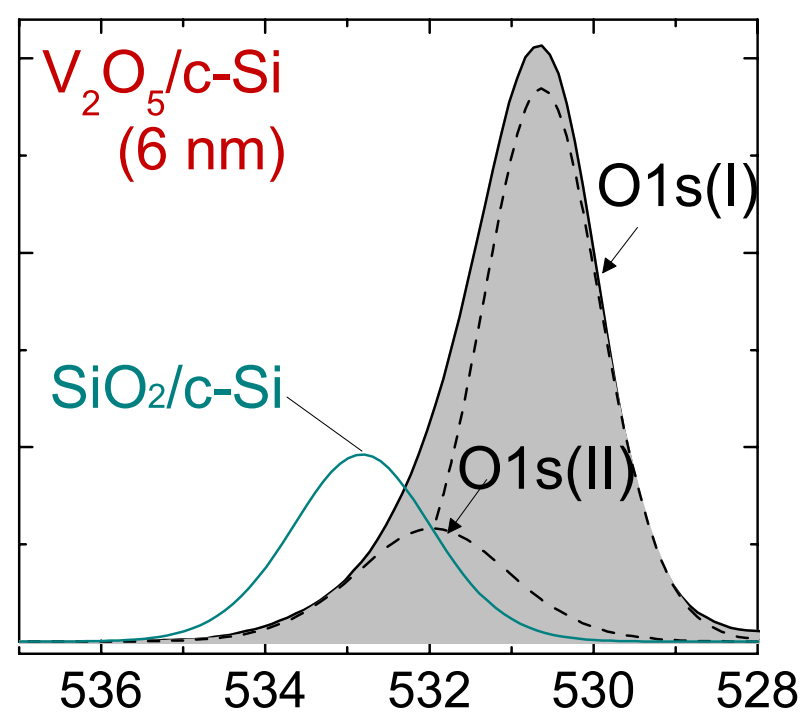

FIG. 4. O1s spectra of the $\mathrm{V}_{2} \mathrm{O}_{5}(6 \mathrm{nn}) /$ interlayer/c-Si region. The larger feature (labeled I, $530.6 \mathrm{eV}$ ) belongs to oxygen in vanadium oxide, while the smaller one (labeled II, 532.0 $\mathrm{eV}$ ) is attributed to oxygen in the $\mathrm{SiO}_{\mathrm{x} \sim 1.5}$ interlayer and to a defective-oxide associated to adventitious oxygen physisorbed during air exposure. Also shown is a reference spectra for $\mathrm{SiO}_{2} / \mathrm{c}-\mathrm{Si}(532.8 \mathrm{eV})$. (Color Online). 
Under these assumptions, the approximate stoichiometry of the $\mathrm{V}_{2} \mathrm{O}_{5}$ films can be calculated from the oxygen to metal $(\mathrm{O} / \mathrm{V})$ ratios, where $\mathrm{O}$ is the total oxygen minus the surface hydroxides, adventitious carbon and interlayer contributions. Figure 5 (left axis) shows the variation of $\mathrm{O} / \mathrm{V}$ ratios with film thickness, observing over-stoichiometric ratios $\mathrm{O} / \mathrm{V}>2.5$ for the thinnest films $\left(\mathrm{V}_{2} \mathrm{O}_{\mathrm{x} \sim 6.3}\right)$. Considering that other oxygen sources have already been neglected, an excess of oxygen near the interface seems correct but in conflict with the presence of $\mathrm{V}^{+4}$ cations attributed to oxygen deficient films [Fig. 3(b)]. Similar ratios have been reported for $\mathrm{Al}_{2} \mathrm{O}_{3} / \mathrm{n}-\mathrm{Si}$ interfaces where excess oxygen is explained as the source of a negative fixed charge in $\mathrm{Al}_{2} \mathrm{O}_{3}\left[{ }^{25,36}\right]$. Finally, it is worth noting that oxygendeficient stoichiometries have been reported as inherent to the bulk of these TMOs (>8 $\mathrm{nm}$ ), with oxygen vacancies, or defect states lying deep within the bandgap, being responsible for their conductivity $\left[{ }^{31}\right]$.

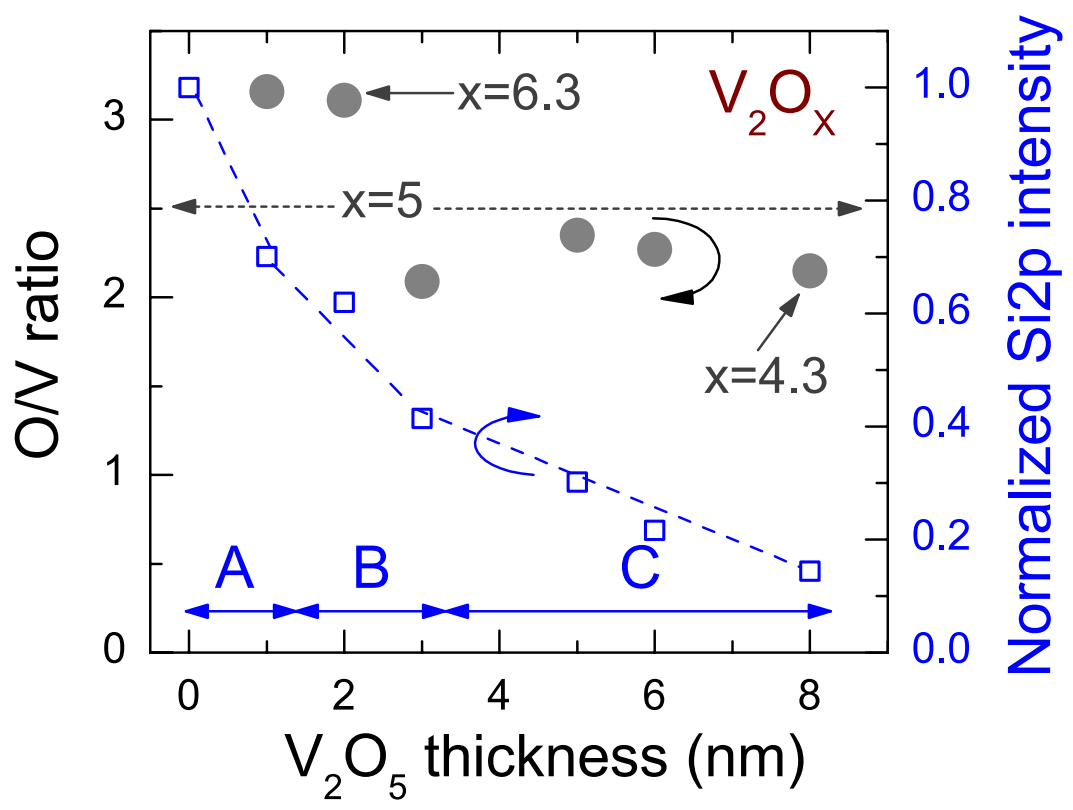

FIG. 5. (Left axis) Evolution of $\mathrm{O} / \mathrm{V}$ ratios as a function of $\mathrm{V}_{2} \mathrm{O}_{5}$ film thickness, indicating a high stoichiometry $\left(\mathrm{V}_{2} \mathrm{O}_{\mathrm{x}>5}\right)$ close to the interface. (Right axis) Normalized area of the substrate $\mathrm{Si} 2 \mathrm{p}^{3} / 2$ peak for each $\mathrm{V}_{2} \mathrm{O}_{5}$ thickness, identifying three growth regimes: (A) $\mathrm{SiO}_{\mathrm{x}}$ 
interlayer formation, (B) layered growth of $\mathrm{V}_{2} \mathrm{O}_{5}$ and (C) nucleation of $\mathrm{V}_{2} \mathrm{O}_{5}$ islands. (Color Online).

A qualitative measure of silicon substrate coverage by $\mathrm{V}_{2} \mathrm{O}_{5}$ can be obtained from plotting the normalized Si2p peak areas as a function film thickness, as shown in Figure 5 (right axis). At a first glance, three growth regimes are observed. During the first nanometers, a rapid linear increase of oxide coverage is observed until a critical thickness of $\sim 3 \mathrm{~nm}$ is reached, followed by a less steep linear growth. Given that the IL thicknesses in Fig. 1 are quite uniform, we propose that the first regime (labeled A) is limited by the reaction rate between $\mathrm{Si}$ and the $\mathrm{TMO}$, where $\mathrm{SiO}_{\mathrm{x}}$ is formed until it saturates at a fixed thickness (and atomic concentration). Next (regime B), $\mathrm{V}_{2} \mathrm{O}_{5}$ continues to deposit on a layer-by-layer basis for several mono-layers until growth occurs by island nucleation (regime C), in what is called a Stranski-Krastanov growth mode $\left[{ }^{26,37}\right]$. Diffusion of species is also possible $\left[{ }^{26}\right]$ but improbable at the low substrate temperatures $\left(\sim 25^{\circ} \mathrm{C}\right)$ at which thermal evaporation takes place.

\section{E. Band bending in c-Si and interface dipole}

Figure 6 depicts the proposed energy band diagram for TMO/n-Si before contact (a) and after the formation of the $\mathrm{SiO}_{\mathrm{x}}$ IL has taken place (b). In the previous sections, passivation of the surface dangling bonds by $\mathrm{SiO}_{\mathrm{x}}$ was proposed as the origin of chemical passivation. Additionally, the TMOs under study tend to induce an inversion (hole-rich) layer on $\mathrm{n}-\mathrm{Si}$ as a result of their particularly large work functions $\left(\phi_{\mathrm{TMO}}>5.5 \mathrm{eV}\right)$, forming the contact needed for photogenerated holes extraction $\left[{ }^{16,38,39}\right]$. This transition from ndoping in the Si bulk to p-doping near the surface manifests as a band bending whose 
magnitude is the built-in potential $\left(V_{b i}\right)$ of the heterojunction. Thus, passivation thorough field-effect is established by driving photogenerated electrons away from the interface.

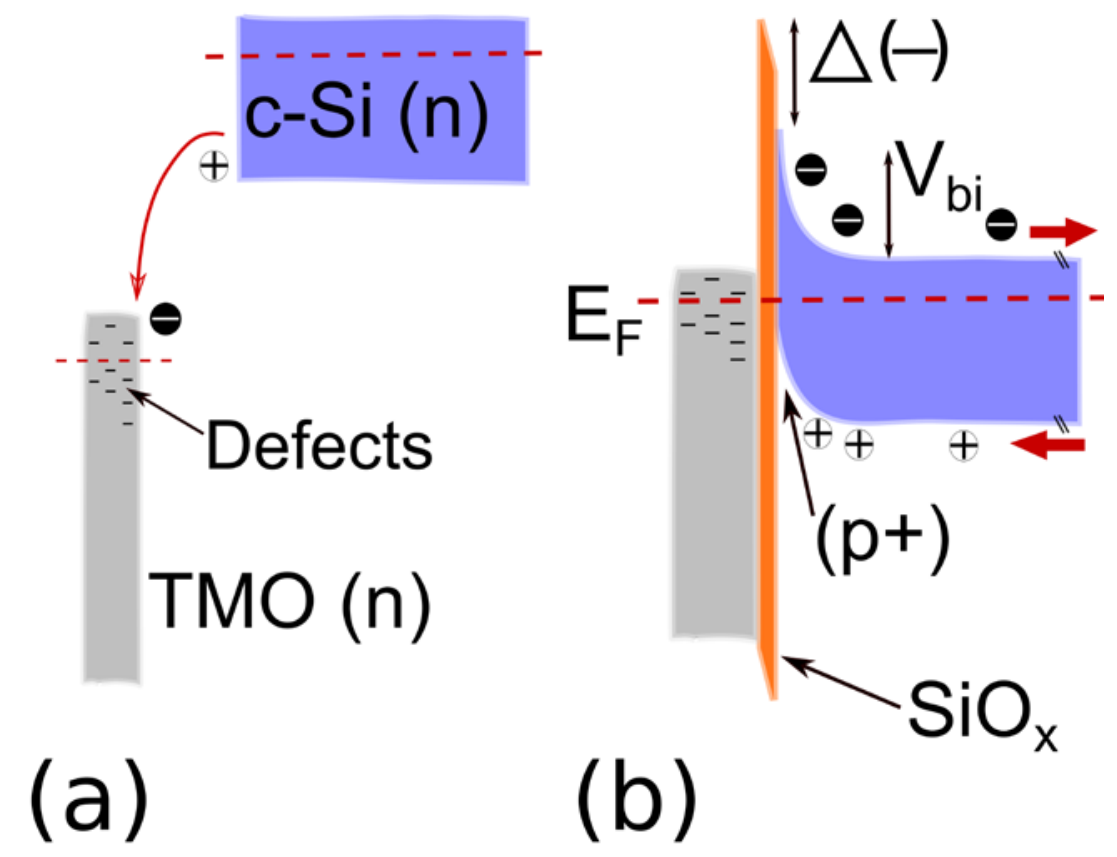

FIG. 6. Proposed band diagram for the TMO/n-Si heterojunction. (a) Before contact, depicting the transfer of electrons from n-type c-Si (oxidation) towards the higher work function TMO (reduction). (b) After contact, following the formation of a passivating $\mathrm{SiO}_{\mathrm{x}}$ interlayer. Electron transfer also induces a $\mathrm{p}^{+}$inversion layer on the c-Si surface and possibly a negative dipole $\Delta(-)$ until Fermi levels reach equilibrium. (Color Online).

Evidence of silicon band bending resulting from TMO deposition can be found in the Si2p core level spectra in Figure 2(a). A shift of the Si2p $\mathrm{p}^{3} / 2$ peak maximum to lower binding energies is observed as the $\mathrm{V}_{2} \mathrm{O}_{5}$ film thickness increases. This shift implies the 'distance' between the Fermi level $\left(E_{\mathrm{Fermi}}\right)$ and the valence band $\left(\mathrm{E}_{\mathrm{VB}}\right)$ is decreasing, or in other words, up-bending occurs as $\mathrm{V}_{2} \mathrm{O}_{5}$ is deposited $\left[{ }^{40}\right]$. A maximum shift of $0.36 \mathrm{eV}$ is obtained for the $5 \mathrm{~nm}$ film, although these values are only approximate given the sources of 
error in these measurements, mainly 1) the mismatch between the photoelectron sampling depth $(<10 \mathrm{~nm})$ and the inversion layer full width $(>100 \mathrm{~nm})$, and 2) the generation of a surface photovoltage from x-ray illumination $\left[{ }^{40}\right]$.

The formation of an inversion layer in n-Si by high work function TMOS can also be explained as a consequence of band alignment across the interface $\left[{ }^{41},{ }^{42}\right]$. Before both materials are contacted, a large electrochemical potential difference exists between them, as defined by the difference in their work functions $\Delta \phi=\phi_{\mathrm{TMO}}-\phi_{\mathrm{nSi}}=5.4-4.2 \mathrm{eV}$. Such energy mismatch is the driving force that initiates $\mathrm{E}_{\mathrm{Fermi}}$ alignment in a series of steps. First, electron transfer occurs from the valence band of $n-S i\left(E_{\mathrm{VB}} \sim 5.2 \mathrm{eV}\right)$ into the defect states lying deep within the TMO bandgap ( $E_{\text {states }}>6 \mathrm{eV}$ ) (see Fig. 6). As explained in Section B, an electron loss in Si results in its oxidation to $\mathrm{SiO}_{\mathrm{x}}$, while the TMO suffers a reduction to lower valence states due to electron gain. Then, as the Si surface is depleted of electrons, the valence band of silicon approaches $\mathrm{E}_{\mathrm{Fermi}}$ and a $\mathrm{p}^{+}$layer is induced. This inversioneffect might be reinforced by negative charges fixed in the IL or in the first $\mathrm{V}_{2} \mathrm{O}_{\mathrm{x}>5}$ layers, as evidenced from the high $\mathrm{O} / \mathrm{V}$ ratios. Since band bending cannot occur indefinitely, we presume the n-Si surface reaches a strong inversion condition with built-in voltage values close to $V_{b i} \sim 0.7 \mathrm{eV}$. At this point, the large $\Delta \phi$ has only been distributed partially in the Si surface and the remaining energy difference needed for equilibrium is allocated by a negative dipole $\Delta(-)$, so that $\Delta \phi=V_{b i}-\Delta$. Similar mechanisms have been previously described for TMO/organic semiconductor systems where electron transfer into the TMO results in the formation of interfacial dipoles and p-doping of the organic Highest Occupied Molecular Orbital (HOMO) levels $\left[{ }^{23,43}\right]$. Regarding the origin of the dipole, it is most probably located in the $\mathrm{SiO}_{\mathrm{x}} / \mathrm{c}-\mathrm{Si}$ interface as surface states, although it could also lie in the 
TMO in the form of uncoordinated (dangling) oxygen atoms, an inherent characteristic of TMOs with large stoichiometries $\left(\mathrm{Mo}_{2} \mathrm{O}_{6}, \mathrm{~W}_{2} \mathrm{O}_{6}\right.$ and $\left.\mathrm{V}_{2} \mathrm{O}_{5}\right)$ and multi-layered bulk structures $\left[{ }^{44,45}\right]$.

\section{CONCLUSIONS}

The mechanisms behind the passivation of n-type c-Si surfaces by thin layers of transition metal oxides $\mathrm{MoO}_{3}, \mathrm{WO}_{3}$ and $\mathrm{V}_{2} \mathrm{O}_{5}$ were investigated by probing the TMO/c-Si interface by HR-TEM, ToF-SIMS and XPS. Chemical passivation due to silicon bonding with oxygen was identified as a sub-stoichiometric $\mathrm{SiO}_{\mathrm{x} \sim 1.5}$ interlayer with thickness averaging $1.9-2.8 \mathrm{~nm}$. This silicon sub-oxide is formed during the partial oxidation of $\mathrm{H}$ terminated silicon by the first TMO monolayers, leaving behind reduced and oxygendeficient species $\left(\mathrm{MoO}, \mathrm{WO}_{2}\right.$ and $\left.\mathrm{VO}_{2}\right)$. The redox reaction was determined to be thermodynamically favorable $\left(-\Delta \mathrm{G}_{\mathrm{rxn}}\right)$ and driven by the large difference in the electrochemical potentials (Fermi levels) of both materials. Therefore, Fermi level equilibration across the interface results not only in $\mathrm{SiO}_{\mathrm{x}}$ formation but also on electron depletion (inversion) of the n-Si surface. Such inversion layer (band bending) thus acts as the hole-selective contact in this type of heterojunction solar cells.

Additionally, the detailed investigation of the $\mathrm{V}_{2} \mathrm{O}_{5} / \mathrm{SiO}_{\mathrm{x}} / \mathrm{c}-\mathrm{Si}$ region by XPS determined that 1) film stoichiometry $\left(\mathrm{V}_{2} \mathrm{O}_{\mathrm{x}}\right)$ varies with thickness, 2) different growth regimes (layer-by-layer, island nucleation) are present, and 3) band bending is observed as a shift of the Si2p core level spectra to lower binding energies, confirming that field-effect passivation (i.e. carrier-concentration gradients) is present as well.

Overall, the described behavior of the TMO/c-Si interface allows for further improvements in its passivating properties, including surface functionalization, $\mathrm{H}_{2}$ diffusion 
to enhance chemical passivation or fine-tuning of TMO stoichiometry by other deposition methods (sputtering, atomic layer deposition). Once a genuine passivating/selective contact is developed, while maintaining (or improving) the conversion efficiency of the device, its eventual implementation could lower processing costs and enhance the competitiveness of c-Si photovoltaics.

\section{ACKNOWLEDGEMENT}

The authors would like to thank: Montserrat Dominguez (XPS analyses) and Trifon Trifonov (FIB) from Centre de Recerca en Nanoenginyeria - Universitat Politècnica de Catalunya; Joaquim Portillo (HR-TEM) from Centres Científics i Tecnològics - Universitat de Barcelona; and Judith Linacero (ToF-SIMS) from IBEC Nanotechnology Platform. This work has been supported by the Spain government under projects ENE2013-48629-C4-1-R and ENE2014-56237-C4-1-R, with financial support from Mexico’s grant program CONACyT.

\section{REFERENCES}

1. Taguchi, M. et al. 24.7\% Record efficiency HIT solar cell on thin silicon wafer. IEEE J. Photovoltaics 4, 96-99 (2014).

2. Battaglia, C., Cuevas, A. \& De Wolf, S. High-efficiency Crystalline Silicon Solar Cells: Status and Perspectives. Energy Environ. Sci. 9, 1552-1576 (2016).

3. Cuevas, A., Allen, T. \& Bullock, J. Skin care for healthy silicon solar cells. 2015 IEEE 42nd Photovolt. Spec. Conf. 1-6 (2015). doi:10.1109/PVSC.2015.7356379

4. Melskens, J. et al. Concepts and prospects of passivating contacts for crystalline silicon solar cells. in 42nd IEEE Photovolt. Spec. Conf. (2015). 
5. Zielke, D., Pazidis, A., Werner, F. \& Schmidt, J. Organic-silicon heterojunction solar cells on n-type silicon wafers: The BackPEDOT concept. Sol. Energy Mater. Sol. Cells 131, 110-116 (2014).

6. Xu, D., Yu, X., Zuo, L. \& Yang, D. Interface engineering and efficiency improvement of monolayer graphene-silicon solar cells by inserting an ultra-thin LiF interlayer. RSC Adv. 5, 46480-46484 (2015).

7. Zhang, Y. et al. High efficiency hybrid PEDOT:PSS/nanostructured silicon Schottky junction solar cells by doping-free rear contact. Energy Environ. Sci. 8, 297-302 (2015).

8. Nagamatsu, K. A. et al. Titanium dioxide/silicon hole-blocking selective contact to enable double-heterojunction crystalline silicon-based solar cell. Appl. Phys. Lett. 106, 123906 (2015).

9. Ziegler, J. et al. Plasma-enhanced atomic-layer-deposited $\mathrm{MoO}$ x emitters for silicon heterojunction solar cells. Appl. Phys. A 120, 2-7 (2015).

10. Boccard, M., Ding, L., Koswatta, P., Bertoni, M. I. \& Holman, Z. Evaluation of metal oxides prepared by reactive sputtering as carrier-selective contacts for crystalline silicon solar cells. Proc. 42nd IEEE Photovoltaics Spec. Conf. 1-3 (2015).

11. Bivour, M., Temmler, J., Steinkemper, H. \& Hermle, M. Molybdenum and tungsten oxide: High work function wide band gap contact materials for hole selective contacts of silicon solar cells. Sol. Energy Mater. Sol. Cells 142, 34-41 (2015).

12. Battaglia, C. et al. Silicon heterojunction solar cell with passivated hole selective MoOx contact. Appl. Phys. Lett. 104, 113902 (2014).

13. Bullock, J. et al. Efficient silicon solar cells with dopant-free asymmetric 
heterocontacts - Sup Mat. Nat. Energy 15031 (2016). doi:10.1038/nenergy.2015.31

14. Yoon, W. et al. Transparent conducting oxide-based, passivated contacts for high efficiency crystalline Si solar cells. Photovolt. Spec. Conf. (PVSC), 2015 IEEE 42nd 1-4 (2015). doi:10.1017/CBO9781107415324.004

15. Islam, R., Shine, G. \& Saraswat, K. C. Schottky barrier height reduction for holes by Fermi level depinning using metal/nickel oxide/silicon contacts. Appl. Phys. Lett. 105, (2014).

16. Gerling, L. G. et al. Transition metal oxides as hole-selective contacts in silicon heterojunctions solar cells. Sol. Energy Mater. Sol. Cells 145, 109-115 (2016).

17. Liao, B., Hoex, B., Aberle, A. G., Chi, D. \& Bhatia, C. S. Excellent c-Si surface passivation by low-temperature atomic layer deposited titanium oxide. Appl. Phys. Lett. 104, 253903 (2014).

18. Yang, X. et al. High-Performance $\mathrm{TiO}_{2}$-Based Electron-Selective Contacts for Crystalline Silicon Solar Cells. Adv. Mater. (2016). doi:10.1002/adma.201600926

19. Greiner, M. T. \& Lu, Z.-H. Thin-film metal oxides in organic semiconductor devices: their electronic structures, work functions and interfaces. NPG Asia Mater. 5, e55 (2013).

20. Gerling, L. G. et al. Back junction n-type silicon heterojunction solar cells with V2O5 hole-selective contact. Energy Procedia Submitted, (2016).

21. Geissbühler, J. et al. 22.5\% Efficient Silicon Heterojunction Solar Cell With Molybdenum Oxide Hole Collector. Appl. Phys. Lett. 107, 081601 (2015).

22. DeBenedetti, W. J. I. \& Chabal, Y. J. Functionalization of oxide-free silicon surfaces. J. Vac. Sci. Technol. A Vacuum, Surfaces, Film. 31, 050826 (2013).

23. Meyer, J. et al. Transition metal oxides for organic electronics: energetics, device 
physics and applications. Adv. Mater. 24, 5408-5427 (2012).

24. Wilk, G. D., Wallace, R. M. \& Anthony, J. M. High-k gate dielectrics: Current status and materials properties considerations. J. Appl. Phys. 89, 5243-5275 (2001).

25. Werner, F. et al. Electronic and chemical properties of the c-Si/Al2O3 interface. $J$. Appl. Phys. 109, 2-8 (2011).

26. Li, X. L., Xiang, W. F., Lu, H. B. \& Mai, Z. H. Studies of the interfacial structure of LaAlO3 thin films on silicon by x-ray reflectivity and angle-resolved x-ray photoelectron spectroscopy. J. Appl. Phys. 97, 124104 (2005).

27. Reed, T. B. Free energy of formation of binary compounds: an atlas of charts for high-temperature chemical calculations. (MIT Press, 1971).

28. Himpsel, F. J., McFeely, F. R., Taleb-Ibrahimi, A. \& Yarmoff, J. A. Microscopic structure of the SiO2/Si interface. Phys. Rev. B 38, 6084 (1988).

29. Moldovan, A. et al. Simple Cleaning and Conditioning of Silicon Surfaces with UV/Ozone Sources. Energy Procedia 55, 834-844 (2014).

30. Biesinger, M. C., Lau, L. W. M., Gerson, A. R. \& Smart, R. S. C. Resolving surface chemical states in XPS analysis of first row transition metals, oxides and hydroxides: Sc, Ti, V, Cu and Zn. Appl. Surf. Sci. 257, 887-898 (2010).

31. Greiner, M. T., Chai, L., Helander, M. G., Tang, W.-M. \& Lu, Z.-H. Metal/MetalOxide Interfaces: How Metal Contacts Affect the Work Function and Band Structure of MoO 3. Adv. Funct. Mater. 23, 215-226 (2013).

32. Gerling, L. G., Mahato, S., Voz, C., Alcubilla, R. \& Puigdollers, J. Characterization of Transition Metal Oxide/Silicon Heterojunctions for Solar Cell Applications. Appl. Sci. 5, 695-705 (2015).

33. Liang, Z. et al. Interaction at the silicon/transition metal oxide heterojunction 
interface and its effect on the photovoltaic performance. Phys. Chem. Chem. Phys. 17, 27409-27413 (2015).

34. Ding, L., Boccard, M., Holman, Z. C. \& Bertoni, M. I. Evaluation of Transition Metal Oxides as Carrier-Selective Contacts for Silicon Heterojunction Solar Cells Contacting silicon heterojunction solar cells. MRS Spring Meet. 2015

35. Greiner, M. T., Helander, M. G., Wang, Z. Bin, Tang, W. M. \& Lu, Z. H. Effects of processing conditions on the work function and energy-level alignment of $\mathrm{NiO}$ thin films. J. Phys. Chem. C 114, 19777-19781 (2010).

36. Naumann, V., Otto, M., Wehrspohn, R. B., Werner, M. \& Hagendorf, C. Interface and Material Characterization of Thin ALD-Al2O3 Layers on Crystalline Silicon. Energy Procedia 27, 312-318 (2012).

37. Hu, X. et al. The interface of epitaxial SrTiO3 on silicon: In situ and ex situ studies. Appl. Phys. Lett. 82, 203-205 (2003).

38. Battaglia, C. et al. Hole Selective MoOx contact for Si solar cells. Nano Lett. 14, 967-971 (2014).

39. Bullock, J., Cuevas, A., Allen, T. \& Battaglia, C. Molybdenum oxide MoOx: A versatile hole contact for silicon solar cells. Appl. Phys. Lett. 105, 232109 (2014).

40. Gleason-Rohrer, D. C., Brunschwig, B. S. \& Lewis, N. S. Measurement of the band bending and surface dipole at chemically functionalized Si(111)/vacuum interfaces. J. Phys. Chem. C 117, 18031-18042 (2013).

41. Bisquert, J. Nanostructured Energy Devices: Equilibrium Concepts and Kinet- ics. (CRC Press, 2014).

42. Wurfel, U., Cuevas, A. \& Wurfel, P. Charge Carrier Separation in Solar Cells. IEEE J. Photovoltaics 5, 461-469 (2015). 
43. Irfan, Zhang, M., Ding, H., Tang, C. W. \& Gao, Y. Strong interface p-doping and band bending in $\mathrm{C60}$ on $\mathrm{MoO}$ x. Org. Electron. physics, Mater. Appl. 12, 1588-1593 (2011).

44. Guo, Y. \& Robertson, J. Origin of the high work function and high conductivity of MoO3. Appl. Phys. Lett. 105, 222110 (2014).

45. Hermann, K. et al. Properties and identification of oxygen sites at the V2O5(010) surface: theoretical cluster studies and photoemission experiments. J. Electron Spectros. Relat. Phenomena 98-99, 245-256 (1999).

\section{FIGURE LIST}

FIG. 1. HR-TEM images of the ITO/TMO/c-Si heterostructures showing an interlayer between c-Si and $\mathrm{MoO}_{3}(\mathrm{a}-\mathrm{b}), \mathrm{WO}_{3}(\mathrm{c})$ and $\mathrm{V}_{2} \mathrm{O}_{5}(\mathrm{~d})$.

FIG. 2. ToF-SIMS depth profile for the ITO/TMO/c-Si heterostructures showing a $\mathrm{SiO}_{2}{ }^{-}$ signal at the interface between c-Si and $\mathrm{MoO}_{3}(\mathrm{a}-\mathrm{b}), \mathrm{WO}_{3}(\mathrm{c})$ and $\mathrm{V}_{2} \mathrm{O}_{5}(\mathrm{~d})$. For each TMO, related reduced species $\left(\mathrm{MoO}^{-}, \mathrm{WO}_{2}^{-}, \mathrm{VO}_{2}^{-}\right)$are also detected near the interface. Also shown in (a) are the $\mathrm{F}^{-}, \mathrm{C}^{-}$and $\mathrm{SiOH}^{-}$signals, attributed to surface contamination of the HF-treated c-Si substrate after air-exposure. (Color Online).

FIG. 3. XPS analysis of the $\mathrm{V}_{2} \mathrm{O}_{5}$ /interlayer/c-Si region at increasing $\mathrm{V}_{2} \mathrm{O}_{5}$ thicknesses $(1-$ $8 \mathrm{~nm}$ ). (a) Si2 $\mathrm{p}^{3} / 2$ doublet spectra showing the characteristic features of the silicon substrate $\left(\mathrm{Si}^{0}, 99.5 \mathrm{eV}\right)$, an stoichiometric $\mathrm{SiO}_{2} / \mathrm{c}-\mathrm{Si}$ reference $\left(\mathrm{Si}^{+4}, 103.2 \mathrm{eV}\right)$ and a substoichiometric $\mathrm{SiO}_{\mathrm{x} \sim 1.5}\left(\mathrm{Si}^{+3}, \sim 102.0 \mathrm{eV}\right)$ attributed to the TMO/c-Si interlayer. Inset shows a detailed view of these features. The peak maxima, marked with a vertical line, shifts to 
lower energies as thickness increases. The Si2 $\mathrm{p}^{1} / 2$ doublet, shifted $0.63 \mathrm{eV}$ to higher binding energies and smaller by a ratio 1:2, is omitted for clarity. (b) Evolution of the vanadium cation species $\mathrm{V}^{+4}$ and $\mathrm{V}^{+5}$ close to the c-Si interface. Inset shows the $\mathrm{V}^{2} \mathrm{p}^{3} / 2$ doublet spectra showing the characteristic features of $\mathrm{V}^{+4}(516.5 \mathrm{eV})$ and $\mathrm{V}^{+5}(518.1 \mathrm{eV})$ states. The $\mathrm{V} 2 \mathrm{p}^{1} / 2$ doublet is shifted $7.6 \mathrm{eV}$ to higher binding energies. (Color Online).

FIG. 4. O1s spectra of the $\mathrm{V}_{2} \mathrm{O}_{5}(6 \mathrm{nn}) /$ interlayer/c-Si region. The larger feature (labeled I, $530.6 \mathrm{eV}$ ) belongs to oxygen in vanadium oxide, while the smaller one (labeled II, 532.0 $\mathrm{eV}$ ) is attributed to oxygen in the $\mathrm{SiO}_{\mathrm{x} \sim 1.5}$ interlayer and to a defective-oxide associated to adventitious oxygen physisorbed during air exposure. Also shown is a reference spectra for $\mathrm{SiO}_{2} / \mathrm{c}-\mathrm{Si}(532.8 \mathrm{eV})$. (Color Online).

FIG. 5. (Left axis) Evolution of $\mathrm{O} / \mathrm{V}$ ratios as a function of $\mathrm{V}_{2} \mathrm{O}_{5}$ film thickness, indicating a high stoichiometry $\left(\mathrm{V}_{2} \mathrm{O}_{\mathrm{x}>5}\right)$ close to the interface. (Right axis) Normalized area of the substrate $\mathrm{Si} 2 \mathrm{p}^{3} / 2$ peak for each $\mathrm{V}_{2} \mathrm{O}_{5}$ thickness, identifying three growth regimes: (A) $\mathrm{SiO}_{\mathrm{x}}$ interlayer formation, (B) layered growth of $\mathrm{V}_{2} \mathrm{O}_{5}$ and (C) nucleation of $\mathrm{V}_{2} \mathrm{O}_{5}$ islands. (Color Online).

FIG. 6. Proposed band diagram for the TMO/n-Si heterojunction. (a) Before contact, depicting the transfer of electrons from n-type c-Si (oxidation) towards the higher work function TMO (reduction). (b) After contact, following the formation of a passivating $\mathrm{SiO}_{\mathrm{x}}$ interlayer. Electron transfer also induces a $\mathrm{p}^{+}$inversion layer on the c-Si surface and possibly a negative dipole $\Delta(-)$ until Fermi levels reach equilibrium. (Color Online). 